\title{
Protein Mdm4
}

National Cancer Institute

\section{Source}

National Cancer Institute. Protein Mdm4. NCI Thesaurus. Code C88220.

Protein Mdm4 (490 aa, 55 kDa) is encoded by the human MDM4 gene. This protein plays a role in the mediation of cell cycle arrest. 